\title{
Estudo de Método Projetual para Sistema Integrado de Identidade Visual, Design da Informação e Orientação
}

\author{
Design method study for integrated Brand Identity, \\ Information Design and Wayfinding systems
}

Fabiano de Vargas Scherer, Gabriel Bischoff Scherer

metodologia de projeto, identidade visual, design da informação, orientação
Este trabalho busca explorar diferentes métodos em design e propor uma metodologia integrada para três de suas áreas: identidade de marca, design da informação e orientação. Esse estudo é aplicado e validado no projeto de revitalização de um importante serviço turístico de Porto Alegre: a Linha Turismo. design methodology, branding identity, information design, wayfinding
This paper aims to explore different design methods and to propose an integrated methodology for three of it's areas: brand identity, information design and wayfinding. This study é applied and validated in the revitalization project of an important tourist service in Porto Alegre: the Tourism Line.

\section{Introdução}

Identidade Visual, também denominada Identidade de Marca, Design da Informação e Orientação são, ao mesmo tempo, atividades distintas e complementares. Embora possuam particularidades, todas se fundamentam em conceitos de design.

Conforme Gibson (2009), a marca é, ainda hoje, a mais importante expressão de identidade de uma corporação ou de um produto. Tanto que os esforços em identidade de marca vêm sendo adotados também por cidades, organizações culturais e instituições que, tradicionalmente, não se associariam a este tipo de esforços estratégicos. Para o autor, é necessário entender que qualquer tipo de contato ou experiência do usuário deve expressar a marca em questão.

Projetos de Orientação, consequentemente, incluem-se nestes esforços de ampliação de percepção de marca. Gibson (2009) avalia que a mescla entre Orientação e Identidade de Marca são indispensáveis para a criação de um ambiente distinto e coerente, conceito denominado placemaking. Um bom sistema de orientação pode ajudar e reforçar a boa imagem de uma cidade. 
Para Sless (2014) o design da informação diz respeito ao relacionamento útil e gratificante entre pessoas e informações. Dessa forma, é possível fazer uma correlação imediata entre os estudos em Orientação e em Design da Informação, tendo em vista que o sucesso de um projeto de Orientação é condicionado pela capacidade do usuário enxergar a informação necessária em um local adequado, compreendê-la e considerá-la relevante para não ser inconscientemente ignorada.

Neste contexto, o método consiste no procedimento, no modo sistematizado de apreender e resolver um problema. E metodologia de projeto, além de poder ser entendida como o estudo dos métodos, apresenta-se também como o conjunto de métodos, técnicas e ferramentas utilizados para o desenvolvimento na resolução de determinado projeto (Bomfim, 1995).

\section{Objetivo}

Este trabalho busca explorar o design e três de suas áreas de atuação: identidade visual, design da informação e orientação. Para isso, analisa métodos relacionados a essas áreas e propõe um método a ser aplicado no projeto integrado de revitalização de um importante serviço turístico da cidade de Porto Alegre: a Linha Turismo, no que diz respeito à Identidade da Marca e os pontos de contato selecionados, à Informação compartilhada com o usuário e à Orientação dos ambientes que integram o serviço.

\section{Metodologia}

Para atingir o objetivo proposto selecionou-se, através de pesquisa bibliográfica e de conhecimento prático prévio, três métodos distintos. A pesquisa não teve o objetivo de esgotar o tema, mas de encontrar relevantes contribuições e subsídios que ajudaram a compor uma metodologia que abarque os requisitos das diferentes áreas envolvidas no projeto. Posteriormente essa metodologia foi aplicada ao serviço Linha Turismo de Porto Alegre com o intuito de verificar sua real contribuição a projetos que integrem essas três áreas do design.

\section{Método Projetual}

Em função do projeto lidar com diferentes áreas do design, as quais possuem particularidades e requisitos próprios de criação, julgou-se necessário pesquisar métodos com diferentes focos para conseguir propor uma metodologia adequada. Essa metodologia precisou não só captar a essência e as características de cada trabalho, mas também definir uma ordem para a criação dos projetos que contivesse uma linearidade coerente e evolutiva com os processos criativos e técnicos. 
Scherer, F. V., \& Scherer, G. B. | Estudo de Método Projetual para Sistema Integrado de Identidade Visual, Design da Informação e Orientação

\section{Método de Frascara}

É uma proposta para Design de Comunicação (Figura 1).

Figura 1 Método de Frascara (2004)

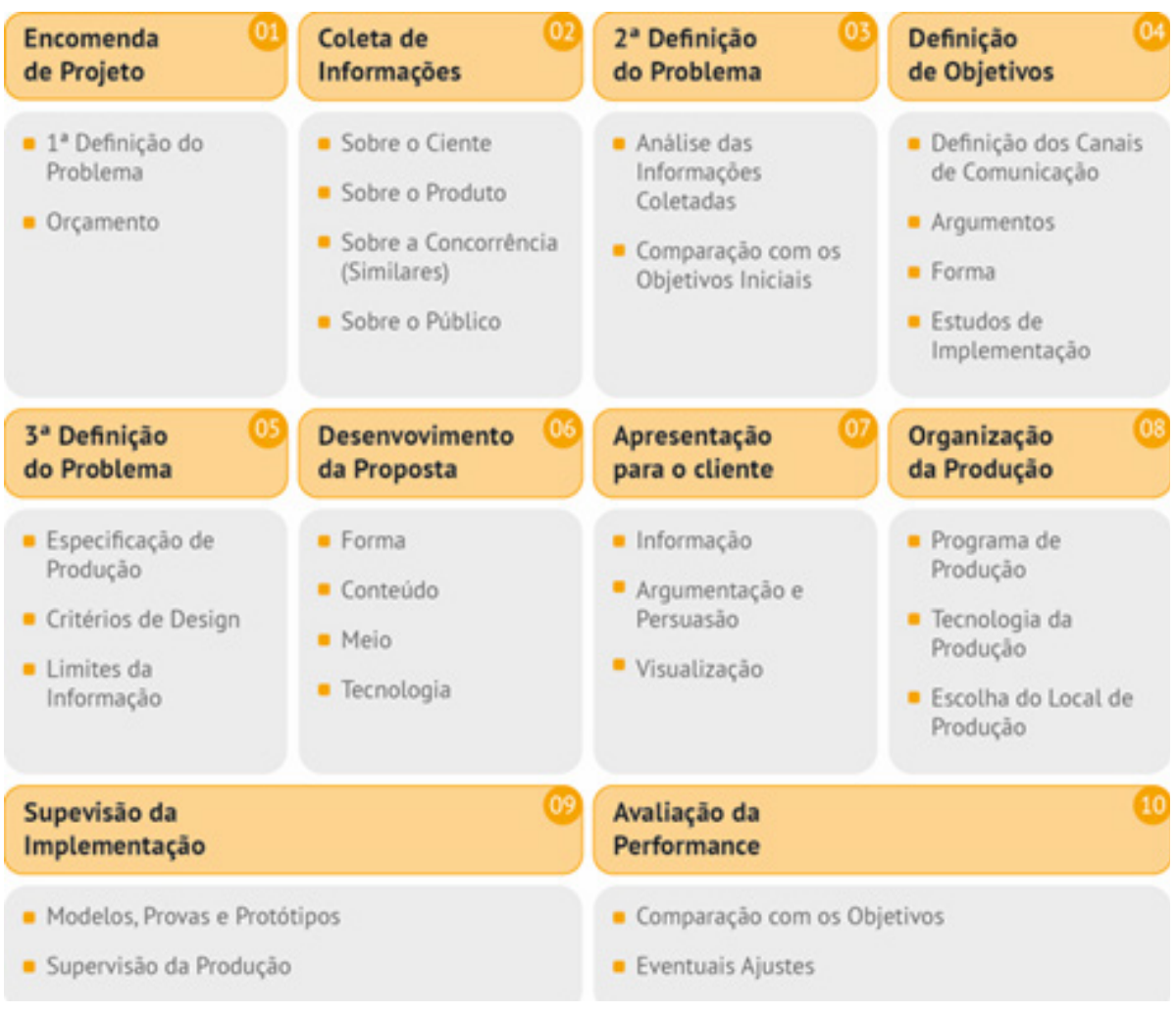

O método foca na identificação dos problemas de projeto e na reflexão sobre os mesmos em termos de definição de objetivos e de cruzamento com dados de pesquisa. Como não se refere a um tipo de trabalho específico em design, o autor acaba aprofundando-se pouco em questões práticas e técnicas, colaborando mais como um guia geral e ordenado para a realização do projeto. Ainda assim, ele possui passos relevantes para a natureza deste trabalho. 


\section{Método do Núcleo de Design Gráfico Ambiental (NDGA)}

Este método foi desenvolvido pelo NDGA UFRGS. Nele realizaram-se análises e comparações com métodos específicos de design de sinalização e com outras de áreas afins. Ele é dividido em três grupos principais: planejamento, projeto e implementação (Cardoso et al, 2011). As etapas de pesquisa desenvolvem-se buscando identificar os agentes e os elementos envolvidos no projeto, ou que podem ser afetados por ele. Isso nota-se na problematização do ambiente, do usuário e da informação, culminando na criação de diretrizes para o projeto. O método ainda está em fase de teste (Figura 2).

Figura 2 Método do NDGA (2010).

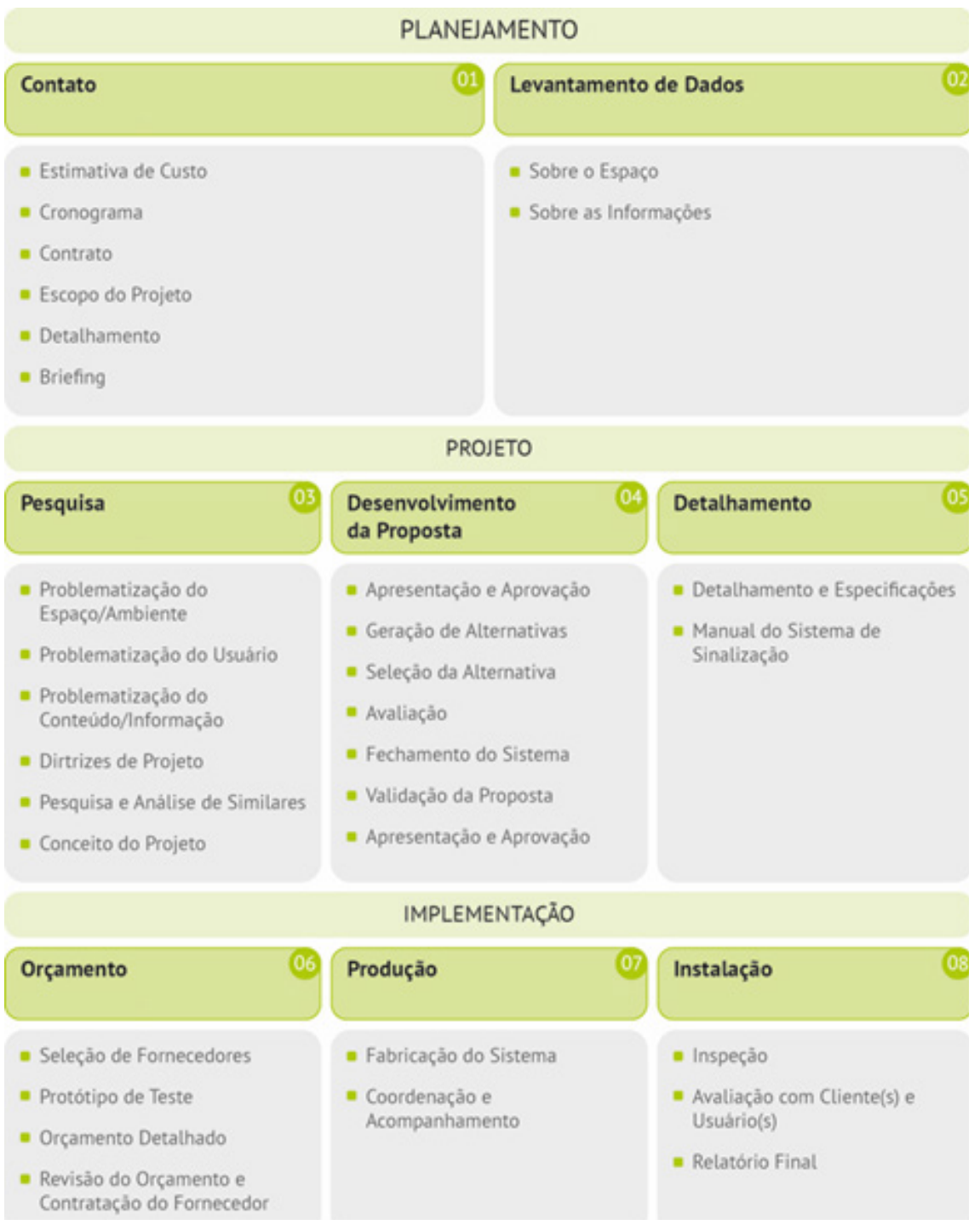




\section{Método de Wheeler}

A proposta de Wheeler (2008) é amplamente reconhecida entre profissionais do design por sua relevância para a criação e para a gestão de marcas. Em seu método (Figura 3), a autora busca ser fiel à realidade dos designers de identidade de marca, inserindo contexto e preocupações específicas da área.

É importante esclarecer que, além do método apresentado a seguir, Wheeler (2008) sugere processos específicos de criação para cada um dos pontos de contato propostos em sua metodologia. Estes, contudo, não serão apresentados neste momento.

Figura 3 Método de Wheeler (2008).

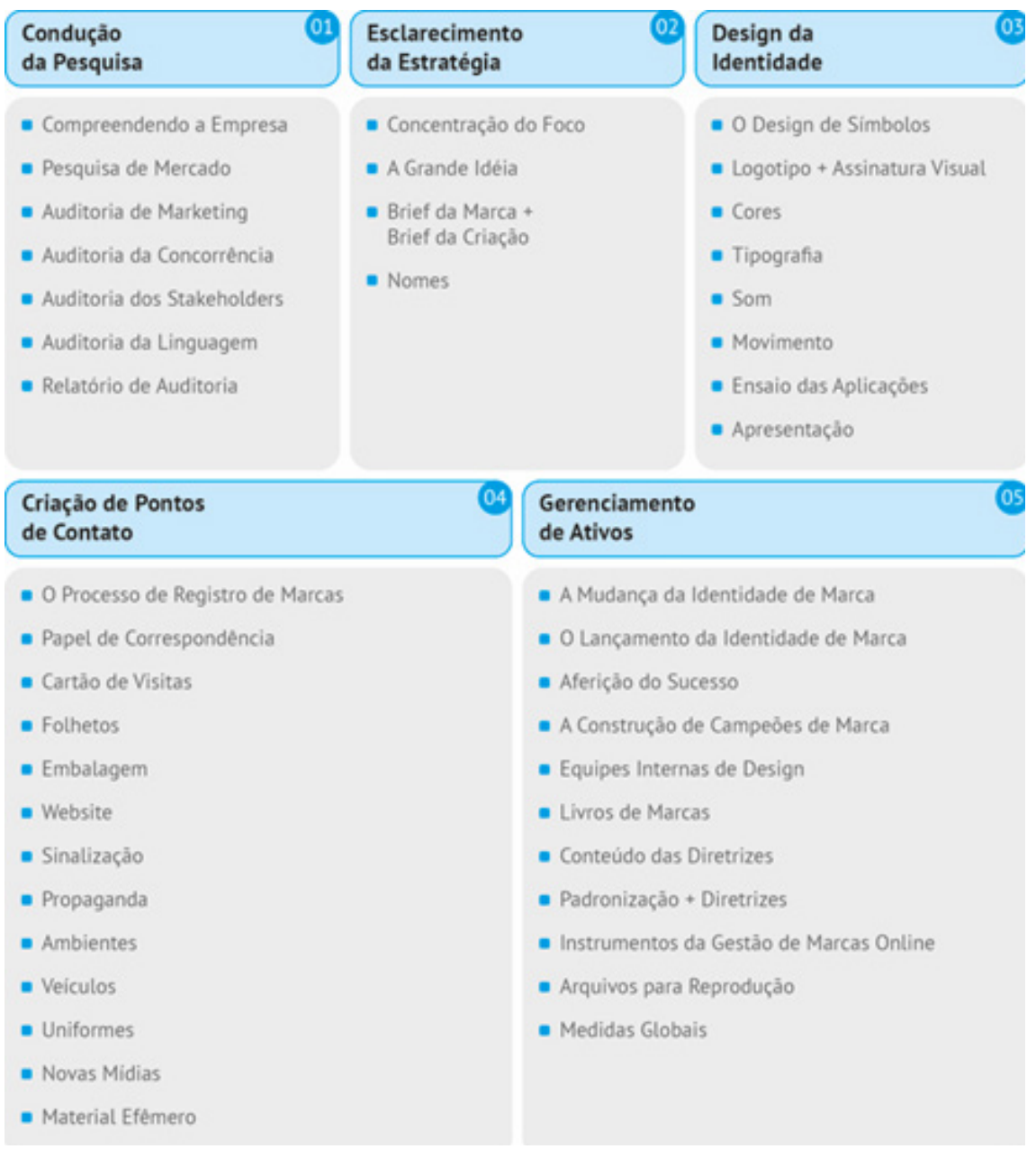




\section{Metodologia Proposta}

A metodologia própria, então, estudou esses três métodos na busca de atingir um resultado efetivo para o trabalho. Inicialmente, definir-se em que ordem os elementos do projeto seriam realizados, mesmo que, até o momento, o escopo ainda não tivesse sido finalizado.

A definição inicial, assim, foi a de qual projeto seria realizado primeiro. O critério para a escolha consistiu na reflexão de qual ofereceria mais substância e mais parâmetros para a realização dos projetos seguintes. Gibson (2009) defende que, embora a construção de identidade para um ambiente comece geralmente pela criação da marca, um programa de orientação completo oferece muito mais substância. No entanto, sendo o projeto composto não apenas de uma identidade de marca e de um projeto de orientação, mas também de outros pontos de contato, julgou-se mais adequado iniciar o projeto pela criação da identidade de marca para lançar uma linguagem consistente às aplicações seguintes. Essa escolha foi ao encontro do método de Wheeler (2008), que insere projetos de natureza semelhante ao de orientação, como sinalização e ambientação, na etapa de Criação de Pontos de Contato da marca.

Uma vez escolhida a ordem de criação dos elementos, começou-se a definir as etapas que comporiam o projeto e em que metodologias se baseariam. Então, adotou-se o método de Frascara (2004) para estruturar as etapas de pesquisa. Embora o autor não especifique algumas ações nem detalhe as aplicações de seu método para diferentes áreas do design, optou-se seu emprego no trabalho em função da explicitação dos problemas de projeto por meio de objetivos. Estes são constantemente utilizados na comparação com novas informações obtidas até atingir um resultado de total compreensão do problema de projeto.

Para complementar, foram aplicadas etapas dos métodos do NDGA (Cardoso et al, 2011) e de Wheeler (2008), inserindo passos específicos de suas respectivas áreas de design e, assim, evitando que a metodologia transformasse-se em uma fórmula genérica e pouco aprofundada. Deslocou-se a realização da "Análise de Similares" da etapa de Coleta de Informações, como era proposta por Frascara (2004), para a etapa de $3^{\underline{a}}$ Definição do Problema. Essa decisão foi tomada com base no método do NDGA (Cardoso, 2011), que propõe a realização da "Análise de Similares" mais próxima às definições conceituais. Assim, a análise constitui o levantamento final antes de refinar as informações em critérios e em delimitadores para o processo conceitual.

Nas etapas de criação, seguiram-se, basicamente, os métodos específicos de cada projeto. Começando pela etapa de Esclarecimento da Estratégia, no item de "Concentração do Foco" compreendem-se as 
características da empresa e às reduzem até um posicionamento e uma essência da marca. Posteriormente, define-se o conceito ou, utilizando o termo de Wheeler (2008), "A Grande Ideia”. Essa maneira de expor a criação do conceito pode ser interpretada de maneira mais elaborada do que uma simples mudança de termo. Uma identidade de marca, assim como qualquer outro produto exposto no mercado, precisa ter diferenciais. Desta maneira, fica explícito no próprio método que a ideia central do projeto precisa ser forte e original. A busca pela grandiosidade, por mais exagerada que pareça, força o designer a perseguir uma ideia genuinamente forte. Essa ideia, assim que definida, será expressa em todos os produtos seguintes.

Na etapa de Design da Identidade, foram retirados itens não contemplados no projeto, como "Som", "Movimento" e "Apresentação" (ao cliente). As etapas de "Cores" e de "Tipografia" foram consideradas como parte dos testes de criação, dentro de "Logotipo + Assinatura Visual”, e, portanto não necessitam estudos Separados. Na Criação dos Pontos de Contato, reduziu-se a quantidade de aplicações, deixando apenas as que foram definidas inicialmente no projeto.

Após a criação da Identidade de Marca e de seus Pontos de Contato, é iniciado o projeto de orientação. Seguindo a estrutura proposta pelo NDGA (Cardoso et al, 2011), foram unidas as etapas de "Geração de Alternativas" e de "Seleção da Alternativa", já que o projeto de orientação foi mais breve, consistindo em apenas um elemento. A etapa é encerrada com o "Fechamento do Sistema", sem a etapa de validação individual do sistema.

Com todos os elementos finalizados e detalhados, o sistema é avaliado em conjunto, passando por validações adequadas à natureza de cada projeto. É previsto, também, “Eventuais Ajustes”, caso as validações demonstrem que o projeto necessita revisões.

Por fim, é prevista a etapa de Detalhamento, na qual se formaliza todo o sistema por meio da criação do manual de especificações. O conteúdo previsto nesse documento são aqueles definidos por Wheeler (2008) no "Conteúdo das Diretrizes", no qual a autora sugere a organização de um Manual de Identidade Visual, e por Cardoso et al (2011) no "Manual do Sistema de Sinalização". A etapa foi chamada de "Manual do Sistema".

A seguir, a Figura 4 apresenta o resultado da metodologia proposta. Sua representação utiliza as cores Laranja (Método de Frascara), Verde (Método do NDGA) e Azul (Método de Wheeler) para explicitar a origem de cada etapa. 
Figura 4 Metodologia proposta.

\begin{tabular}{|c|c|c|c|}
\hline $\begin{array}{l}\text { Encomenda } \\
\text { de Projeto }\end{array}$ & $\begin{array}{l}\text { Coleta de } \\
\text { Informaçōes }\end{array}$ & $\begin{array}{l}2^{2} \text { Definição } \\
\text { do Problema }\end{array}$ & $\begin{array}{l}\text { Definição } \\
\text { de Objetivos }\end{array}$ \\
\hline $\begin{array}{l}\text { - Compreendendo a } \\
\text { Empresa } \\
\text { - } 1^{2} \text { Definição do } \\
\text { Problema }\end{array}$ & $\begin{array}{l}\text { - Pesquisa de Mercado } \\
\text { - Auditoria de } \\
\text { Marketing } \\
\text { - Sobre o Produto } \\
\text { - Sobre o Espaço }\end{array}$ & $\begin{array}{l}\text { - Análise das } \\
\text { Informaç̋̄es } \\
\text { Coletadas } \\
\text { - Comparação com os } \\
\text { Objetivos Iniciais }\end{array}$ & = Diretrizes de Projeto \\
\hline $\begin{array}{l}3^{a} \text { Definição } \\
\text { do Problema }\end{array}$ & $\begin{array}{l}\text { Esclarecimento } \\
\text { da Estratégia }\end{array}$ & $\begin{array}{l}\text { Design da } \\
\text { Identidade }\end{array}$ & $\begin{array}{l}\text { Criação de Pontos } 08 \\
\text { de Contato }\end{array}$ \\
\hline $\begin{aligned} & \text { - Problematização do } \\
& \text { Espaço/Ambiente } \\
& \text { - Problematizaçào do } \\
& \text { Conteúdo/Informação } \\
& \text { - Análise de Similares } \\
& \text { = Critérios de Design }\end{aligned}$ & $\begin{array}{l}\text { - Concentração do } \\
\text { Foco } \\
\text { - A Grande Idéia }\end{array}$ & $\begin{array}{l}\text { - Design de } \\
\text { Simbolos } \\
\text { - Logotipo + Assinatura } \\
\text { Visual }\end{array}$ & $\begin{array}{l}\text { - Veiculo } \\
\text { - Ingresso } \\
\text { - Uniformes } \\
\text { - Folheto }\end{array}$ \\
\hline $\begin{array}{l}\text { Desenvolvimento do } \\
\text { Projeto de Orientação }\end{array}$ & \multicolumn{2}{|l|}{$\begin{array}{l}\text { Avaliação da } \\
\text { Performance }\end{array}$} & Detalhamento \\
\hline $\begin{aligned} \text { - Geraçào e Seleçào de } \\
\text { Alternativas } \\
\text { - Fechamento do Sistema }\end{aligned}$ & \multicolumn{2}{|c|}{$\begin{array}{l}\text { - Validaçăo das Propostas } \\
\text { - Eventuais Ajustes }\end{array}$} & - Manual do Sistema \\
\hline
\end{tabular}

\section{Aplicação da Metodologia}

Com o decorrer do processo, observou-se que a compreensão e o entendimento do projeto amadureceram de acordo com a obtenção de informações e de dados sobre o projeto, prática prevista pelo método de Frascara (2004) nas constantes reflexões e reavaliações sobre o real problema de projeto.

Por uma questão de espaço, abaixo serão descritas as etapas de forma bastante sucinta. Para maiores detalhes e informações sobre todo o processo, ver Scherer (2012).

\section{Etapa 01 - Encomenda do Projeto}

A Secretaria Municipal de Turismo de Porto Alegre (SMTUR), responsável pelo serviço da Linha Turismo, foi o foco para o item Compreendendo a Empresa. O site da secretaria forneceu importantes informações e pesquisas que foram utilizadas em análises posteriores.

A Primeira Definição do Problema consistiu em um exercício de reflexão pessoal sobre as áreas do design envolvidas na Linha Turismo. Essa análise apontou Identidade de Marca, Design da Informação e Orientação com áreas onde o serviço poderia ser aperfeiçoado, o que se tornou o escopo inicial do projeto. As análises posteriores deveriam confirmar se essa sugestão era de fato válida. 


\section{Etapa 02 - Coleta de Informações}

Nessa etapa preocupou-se em obter informações de todas as partes interessadas na Linha Turismo. A Pesquisa de Mercado reuniu diversas pesquisas da SMTUR sobre o perfil do usuário e relatórios sobre o desempenho do serviço. Também foram feitos contatos diretamente com a secretaria e acompanhamento constante de notícias e de mídia especializada.

A coleta de materiais como folders, mapas, ingressos do passeio e arquivos digitais da marca foram utilizados para a Auditoria de Markerting (Figura 5). Já a realização do passeio forneceu informações do ônibus para a coleta Sobre o Produto e dos pontos turísticos para a coleta Sobre o Espaço.

Figura 5 Coleta de Informações.
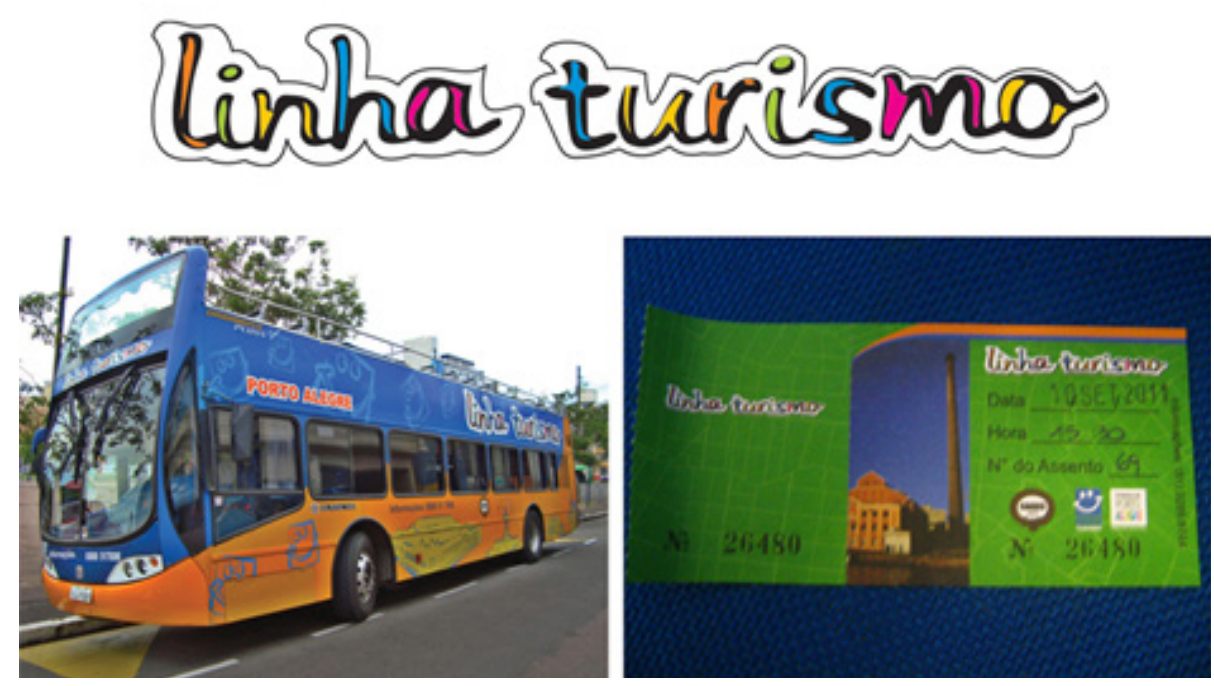

\section{Etapa 03 - Segunda Definição do Problema}

A Análise das Informações Coletadas teve diferentes abordagens. A opinião das pesquisas dos usuários sobre o ônibus e o passeio foi comparada com a própria experiência de ter feito o passeio. A adequação da identidade de marca foi analisada pessoalmente e por meio de pesquisa na internet e o material de divulgação foi avaliado tanto em sua relação com a identidade existente quanto na qualidade da informação fornecida.

A Comparação com os Objetivos Iniciais cruzou as análises com a primeira definição do problema de forma a produzir novas conclusões sobre o projeto. A situação encontrada sustentou a possibilidade de melhorar a Linha Turismo pelas três áreas do design escolhidas: a identidade de marca foi considerada inadequada, os materiais informativos nem sempre explicitam o serviço turístico e os pontos do roteiro poderiam melhorar sua recepção com um novo sistema de orientação. 


\section{Etapa 04 - Definição de Objetivos}

Considerando as pesquisas e as impressões obtidas com a realização do passeio, chegou-se nas Diretrizes de projeto. Primeiramente, estipulou-se que seria feito o redesenho da identidade de marca junto com seus pontos de contato, pois tanto as pesquisas públicas quanto o contato com representantes da SMTUR demonstraram que essa mudança seria positiva. Sobre os materiais de divulgação, entendeu-se que, embora possuíssem pontos positivos, eles nem sempre eram voltados para a Linha Turismo. Os mapas, por exemplo, forneciam uma série de dados relevantes ao turista, porém não esclareciam informações sobre o passeio, como os horários do ônibus e suas rotas. Assim, delimitou-se que o novo material trabalharia a informação com foco principal no serviço turístico. A última definição foi relacionada ao teste do projeto de orientação. Como a Linha Turismo oferece um roteiro que visita os principais pontos turísticos da cidade (Roteiro CentroHistórico) e outro que percorre uma região mais afastada de Porto Alegre (Roteiro Zona Sul), entendeu-se que seria mais viável testar as alternativas em apenas um deles para que análise dos locais não fosse muito extensa. O roteiro escolhido foi Centro-Histórico (Figura 6).

Figura 6 Roteiro Centro-Histórico (fotos e marcação do roteiro no mapa).
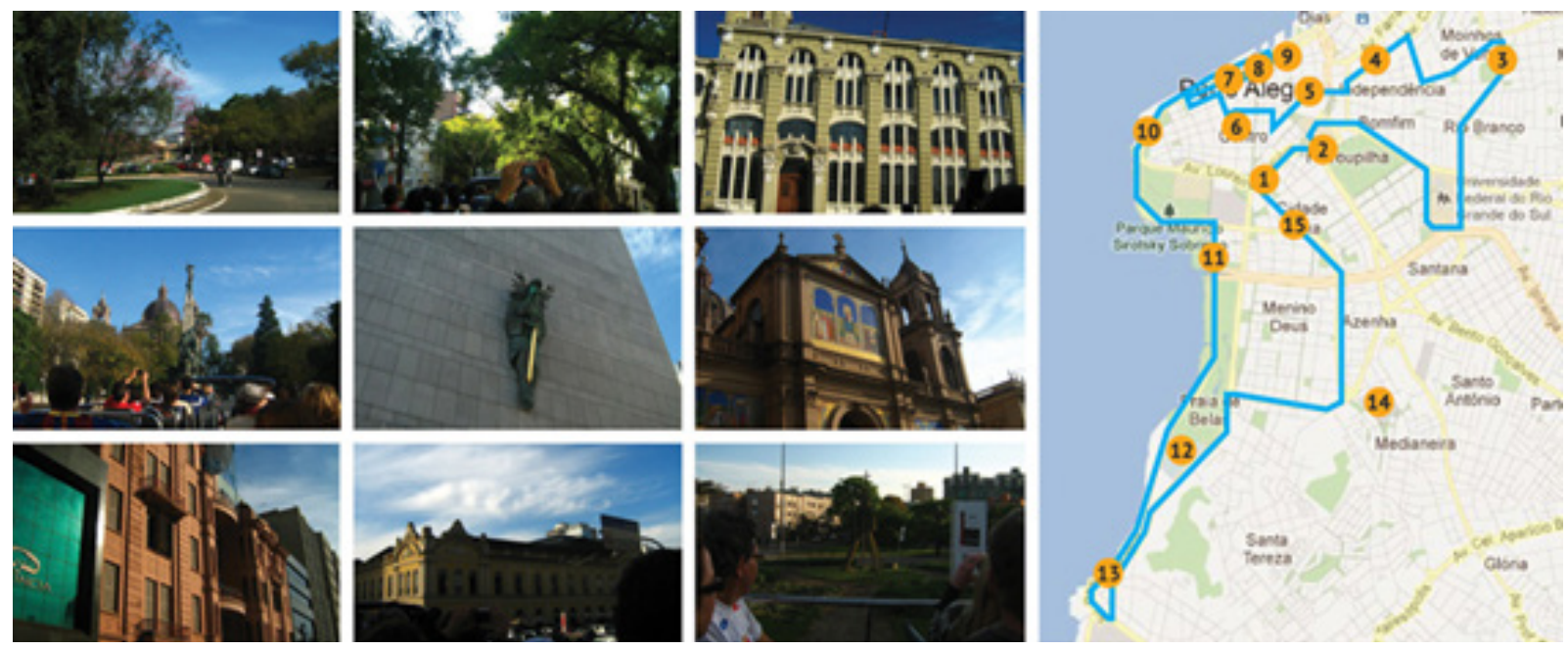

Etapa 05 - Terceira Definição do Problema

Essa etapa iniciou-se com algumas novidades no cenário da Linha Turismo. Um contato da SMTUR confirmou o acréscimo de dois novos ônibus à frota turística e a inclusão de um sistema de paradas, no qual o passageiro teria a possibilidade de descer em cinco dos catorze pontos turísticos do Roteiro Centro-Histórico. Essa alteração foi representativa, pois o passageiro passaria a ter uma integração maior com os locais, e, portanto, o projeto de orientação teria maior visibilidade. 
Dentro desse novo contexto foi realizada a Problematização do Espaço/Ambiente. Nela, cada local do roteiro foi analisado sob a ótica do passageiro. A intenção desse exercício foi identificar pontos relevantes percebidos de sua posição interna ao ônibus para que eles, possivelmente, servissem como um local para o projeto de orientação agir. A Figura 7 mostra a análise de fluxo do ônibus e dos locais relevantes em um dos pontos do roteiro.

Figura 7 Problematização do Espaço/Ambiente.
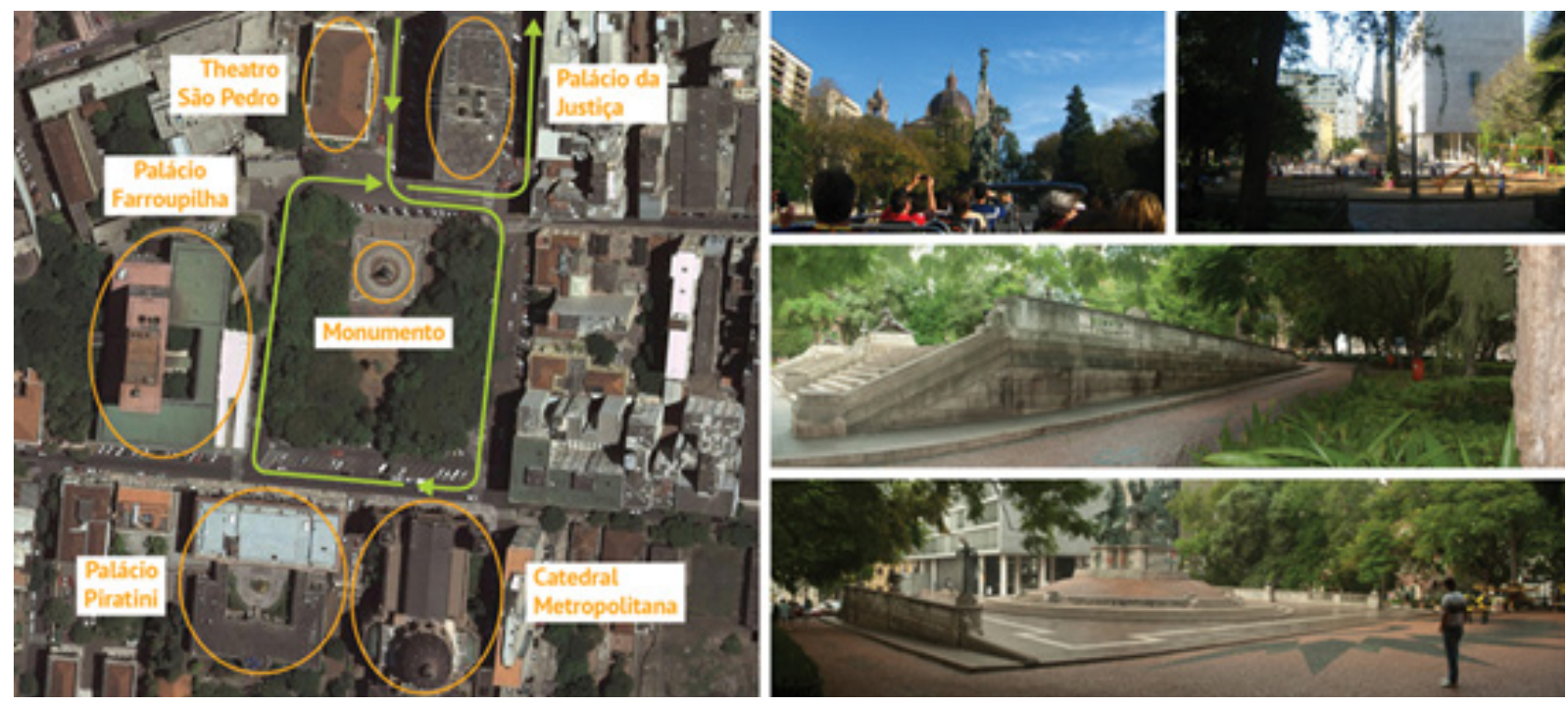

A Problematização do Conteúdo/Informação foi uma reflexão sobre que tipo de elemento de orientação seria adequado aos pontos turísticos. Para isso, utilizou-se a organização proposta por Calori (2007), na qual o sistema de informação é categorizado de acordo com sua função em sete tipos de elemento: identificação, direcional, operacional, interpretativo, advertência, restritivo e honorário.

Dentre eles, entendeu-se que os três últimos citados conflitavam com responsabilidades administrativas dos próprios ambientes e não possuíam um caráter turístico. Assim, as categorias restantes tiveram suas possibilidades estudadas dentro do contexto do projeto e da utilização de elementos gráficos como setas, símbolos, mapas ou outro tipo de grafismos. O resultado dessa análise foi uma lista que explorou as possibilidades da informação sem uma preocupação com o aproveitamento de todas em um elemento de orientação.

Para a Análise de Similares, foram selecionados cinco projetos relevantes para identidade, informação e orientação. Três desses projetos são serviços de ônibus turísticos: "Buenos Aires Bus", "City Sightseeing" e "Linha Turismo de Curitiba". Os outros dois projetos são sistemas de orientação urbana: "Bue: Sistema Siñalético Recoleta" e "Legible London".

O fechamento da etapa deu-se com os Critérios de Design.

Dentro de Espaço/Ambiente, entendeu-se que os locais destacados no material informativo da Linha Turismo como os principais pontos do 
passeio poderiam ser elencados diferentemente. A mudança levou em consideração a pesquisa dos usuários e a própria experiência de ter feito o passeio. Essas alterações, no entanto, não afetariam o número de pontos do roteiro, o caminho realizado pelo ônibus e tampouco as informações compartilhadas pelo guia turístico durante o passeio. Elas compreenderiam, apenas, a lista divulgada do roteiro. Com essa alteração no roteiro, os locais foram todos categorizados em grupos por semelhança. A intenção era filtrar os principais pontos do passeio para que, posteriormente, um deles fosse selecionado como o local de maior relevância para testar o elemento de orientação. Sete locais foram selecionados como possíveis candidatos ao teste.

Os critérios relacionados ao Conteúdo/Informação agiram de maneira a ordenar todas as possibilidades geradas em sua problematização. A escolha foi sempre pautada na relação dessa informação com a Linha Turismo e na identificação do local como as principais preocupações. Ainda assim, foi possível propor uma organização que contivesse informações turísticas complementares a essas principais. A Figura 8 esquematiza o tipo de informação do elemento, diferenciando o que é fixo e o que varia de acordo com o local.

Figura 8 Informações do elemento de orientação.

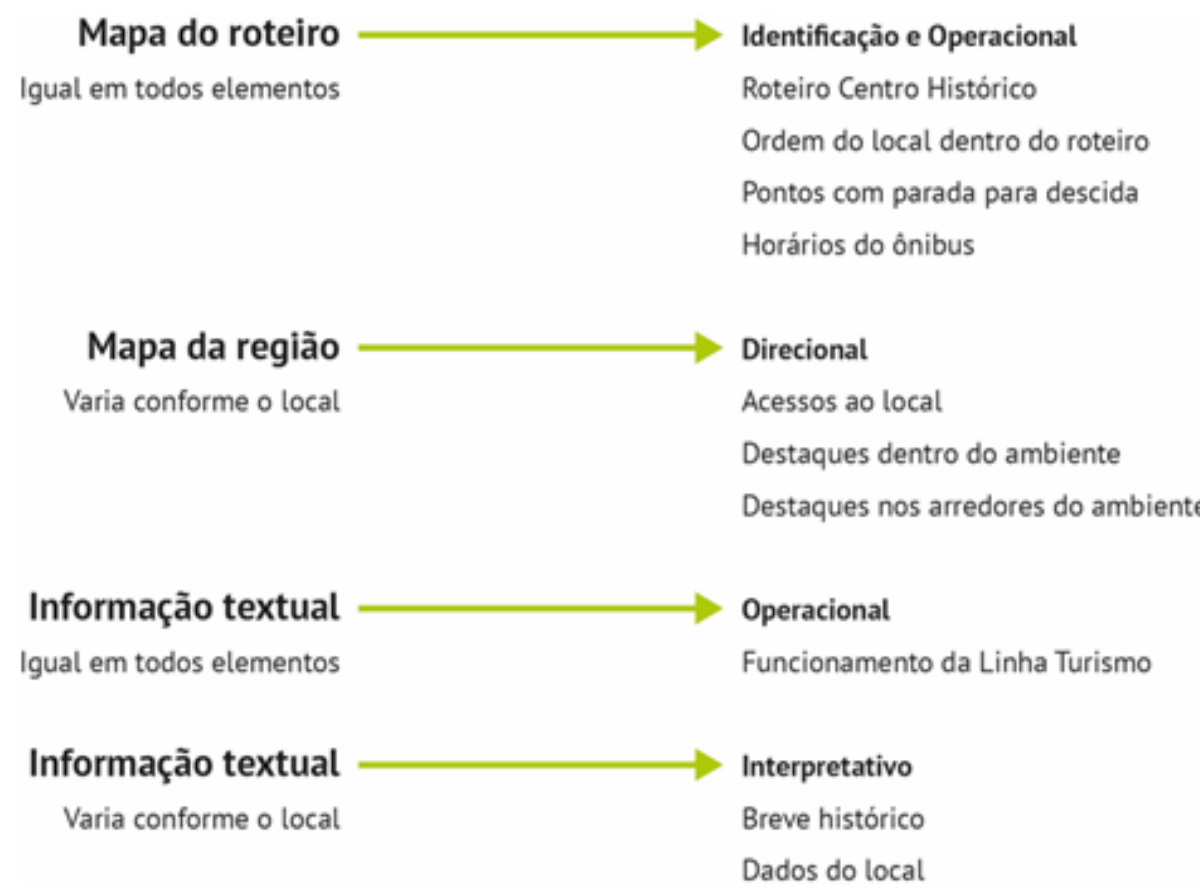




\section{Etapa 06 - Esclarecimento da Estratégia}

Segundo Wheeler (2008), tudo o que foi aprendido nas pesquisas e auditorias é destilado em uma ideia unificadora e em uma estratégia de posicionamento. A Concentração do Foco consistiu em um processo que resgatou o contexto da Linha Turismo e foi reduzindo seu foco até a marca. Na busca pela essência da marca, foram feitos diversos mapas mentais para tentar encontrar ideias significativas referentes à cidade de Porto Alegre e à Linha Turismo. Eventualmente, um dos mapas forneceu o termo "contemplação", o qual foi escolhido para exploração e refinamento em uma ideia concreta.

Continuando com o processo em A Grande Ideia, foram realizados outros mapas mentais que buscaram explorar "contemplação" visualmente e semanticamente. Os resultados foram trabalhados em uma espécie de slogan para a Linha Turismo, com a ideia de que o próprio serviço turístico sugerisse o ato de contemplar. Após uma geração de alternativa, escolheu-se o mote "Contemple Porto Alegre". A etapa foi concluída com a realização de um painel visual com imagens referentes ao conceito de contemplação, uma possibilidade de sugestão de ideias ou gestos úteis para a criação da identidade (Figura 9).

Figura 9 Painel visual de "contemplação".
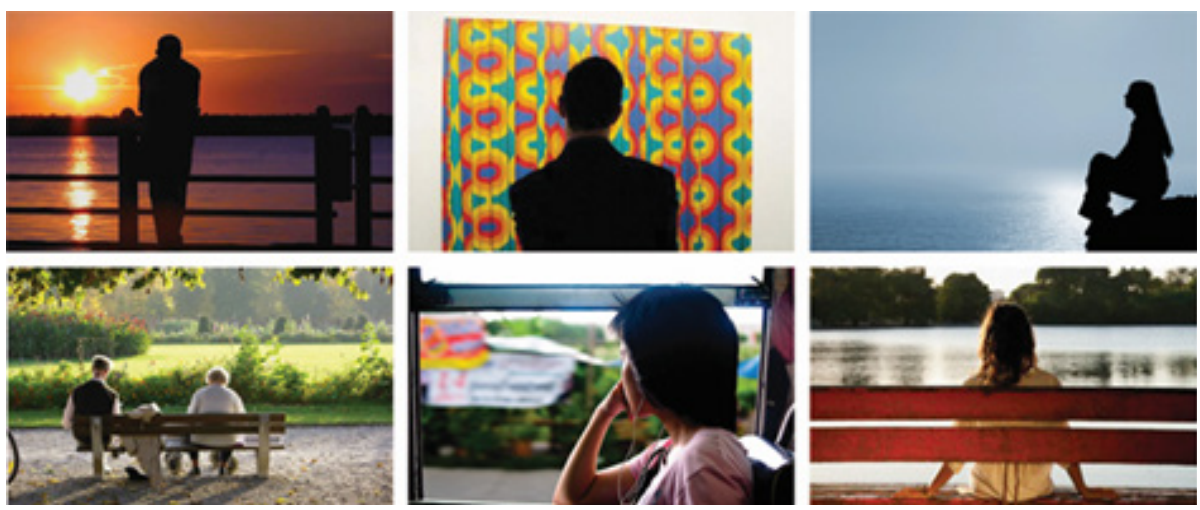

\section{Etapa 07 - Design da Identidade}

Essa etapa compreende ao início do processo de criação. Começando com O Design de Símbolos, buscou-se a exploração de imagens características de Porto alegre como o pôr do sol na orla do rio Guaíba e as atividades ao ar livre em parques e praças. Os primeiros testes, que sempre buscaram integrar essas ideias com a imagem do ônibus, mostraram-se muito literais e/ou inexpressivos. Então se explorou uma abordagem um pouco mais subjetiva, como a representação de gestos de pessoas contemplando paisagens ou sentadas em bancos. Assim, chegou-se a uma proposta minimalista de duas pessoas, um homem e uma mulher, um ao lado do outra em posições que remetiam a imagens 
do painel visual, com um estilo de desenho pictográfico. Na etapa de Logotipo + Assinatura Visual, os estudos continuaram e, após diversos testes, estudos tipográficos e cromáticos e ajustes de modulação e espaçamento, a identidade de marca foi finalizada (Figura 10).

Figura 10 Identidade de marca finalizada.

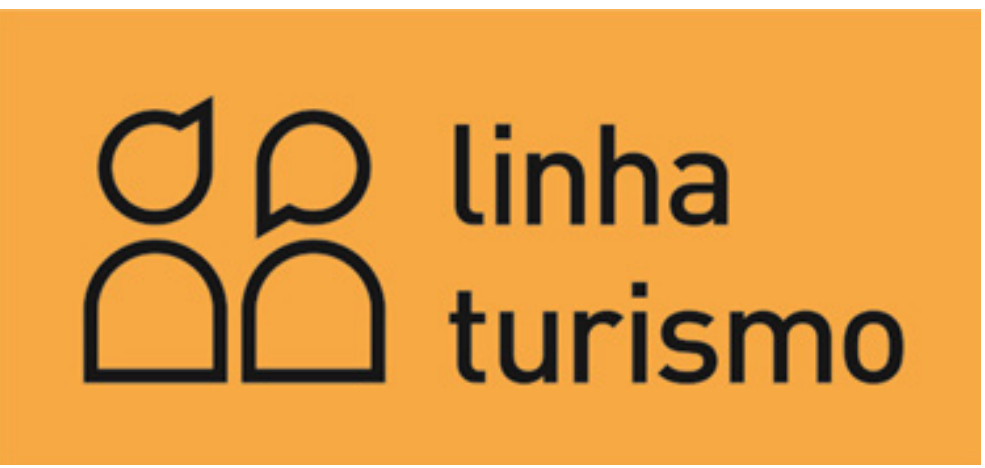

\section{Etapa 08 - Criação de Pontos de Contato}

Em função da comunicação do Ônibus ser o elemento mais visível e chamativo dentre os pontos de contato, julgou-se que sua conclusão forneceria uma boa quantidade de soluções estéticas. Seus primeiros esboços, embora não muito conclusivos, sugeriram a utilização de pictogramas para representar os tipos de locais visitados no passeio. A criação dessa família de pictogramas foi utilizada não só para auxiliar na informação compartilhada com o usuário, mas também para criar uma assinatura complementar à identidade principal, utilizando a frase "Contemple Porto Alegre". A Figura 11 mostra a família de pictogramas e a assinatura.

Figura 11 Família de pictogramas e assinatura "Contemple Porto Alegre".

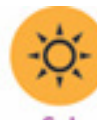

Sol

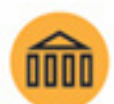

Museu

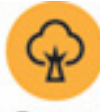

Parque

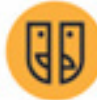

Teatro

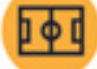

Esporte

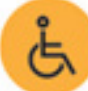

Acesso Universal

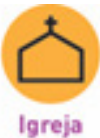

Igreja

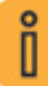

Centro de Informaçōes Turisticas

\section{contemple porto alegre

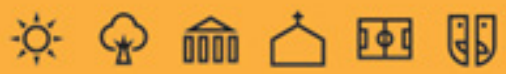


Esse novo material de suporte foi importante para que a comunicação do ônibus fosse finalizada. Nela, utilizou-se o mesmo minimalismo iniciado pelas identidades principal e complementar para chegar ao resultado final (Figura 12).

Figura 12 Comunicação do ônibus.

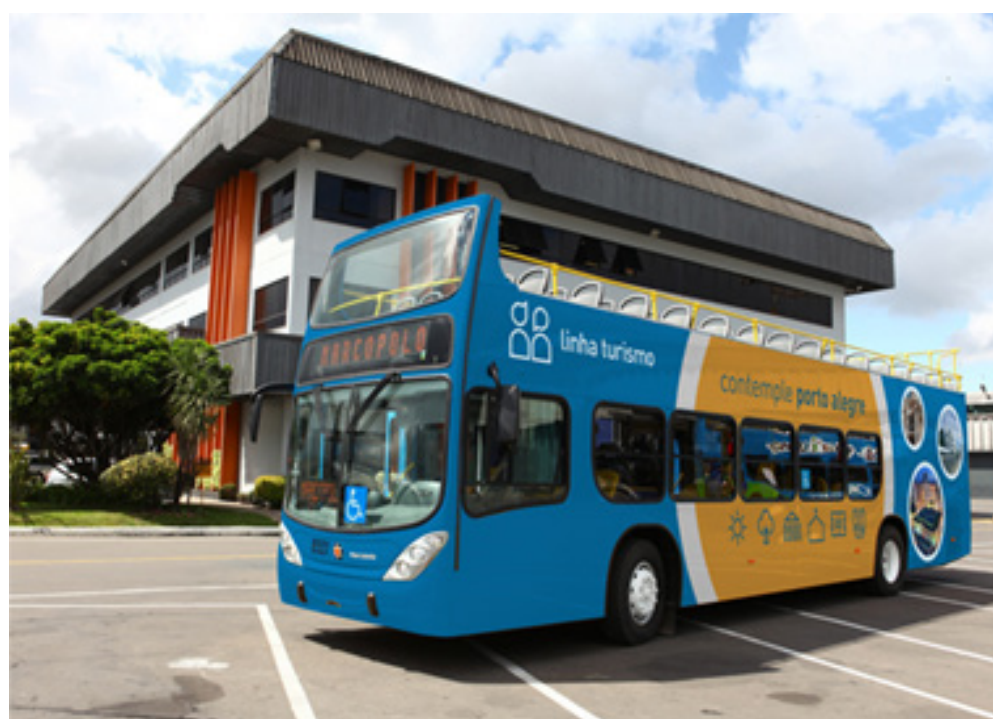

Em função da inclusão do sistema de paradas, o Ingresso (Figura 13) passou a ter mais informações do que tinha anteriormente. A frente possui um sistema para os funcionários marcarem o dia em que o ingresso é válido; o verso apresenta os locais onde o ocorrem o embarque/desembarque com seus respectivos horários discriminados. Toda informação é acompanhada de tradução em inglês e espanhol.

Figura 13 Ingresso

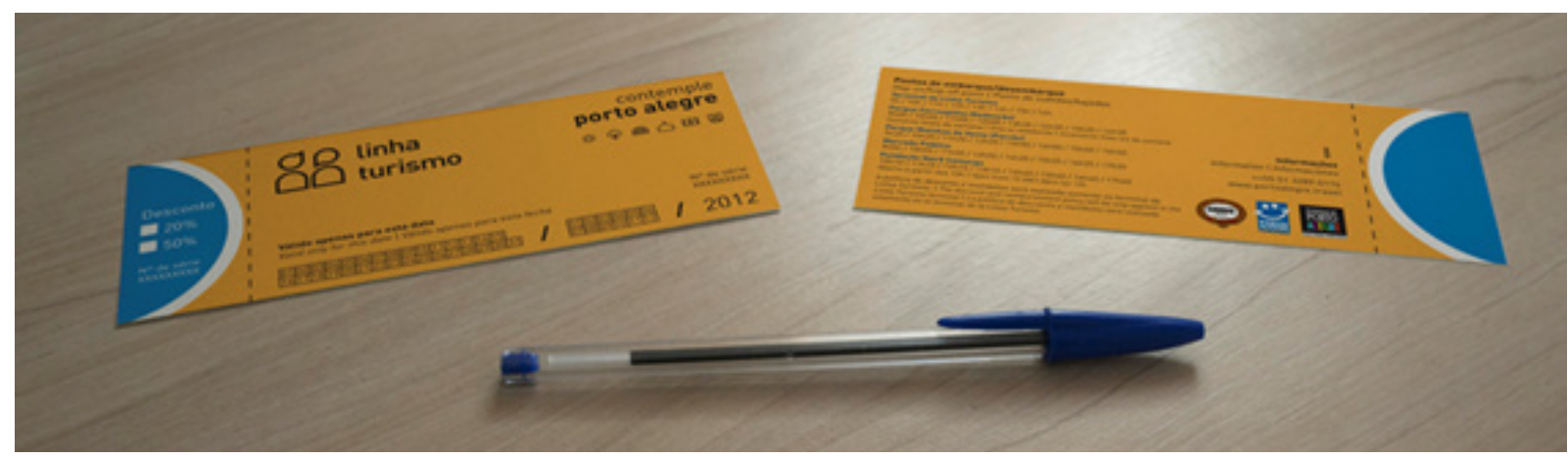


O Uniforme (Figura 14) dos funcionários teve um resultado bem simples. Essa opção foi feita para manter o baixo custo do material, já que a aplicação de uma cor no tecido ou uma área de impressão mais abrangente poderia deixar a produção mais complexa.

Figura 14 Uniforme
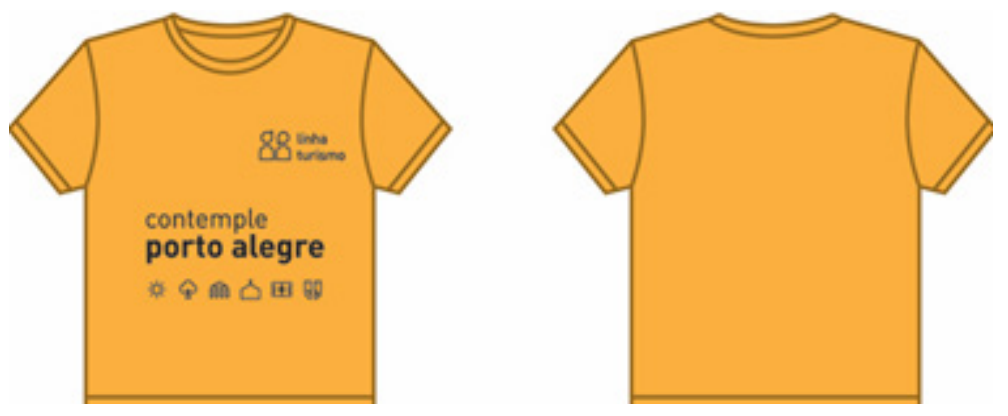

O Folheto representou uma das aplicações mais trabalhosas do sistema. Partindo das diretrizes anteriores sobre o foco da informação sempre na Linha Turismo, o mapa tinha a função de principal de mostrar o caminho realizado pelo ônibus e não fornecer uma guia para a cidade (já que a SMTUR possui materiais próprios para esse uso). Seu desenho foi feito a partir de uma abstração do mapa real, no qual foram definidos módulos e ângulos padrão e suprimidas algumas ruas menores para que seu resultado fosse mais fácil de interpretar.

A frente do folheto possui informações operacionais sobre o ônibus (valores, horário de funcionamento, pontos de venda do ingresso) e uma aplicação da marca e do ônibus em destaque. O verso inclui o mapa e a lista de pontos de destaque do roteiro. Essa lista informa os locais de embarque/desembarque e utiliza o sistema de pictogramas para informar esses ambientes oferecem aos turistas. A Figura 18, mais em frente, mostra o resultado do folheto após passar pela etapa de ajustes.

\section{Etapa 09 - Desenvolvimento do Projeto de Orientação}

A etapa iniciou com a definição do tradicional Parque Farroupilha, conhecido como "Redenção", como o local para testar o elemento de orientação, entendendo que ele era o local mais complexo do roteiro. A escolha foi feita utilizando um mapa que indica diversos estabelecimentos e pontos por toda a cidade e contabilizando quais locais possuíam maior quantidade de indicações, tanto interna quanto externamente. Isso somado à grande extensão territorial e os diversos ambientes apontou para o parque.

Os primeiros esboços da Geração e Seleção de Alternativa exploraram diversas formas, desde regulares até curvas e orgânicas. Porém logo em avaliações preliminares, entendeu-se que utilizar essas formas mais soltas como suporte para informação dificultava e limitava sua organização. Assim, levando em consideração alguns 
exemplos da análise de similares, optou-se por seguir uma linha mais séria e contida, mantendo a área retangular como suporte da informação e buscando a diferenciação e a aplicação da identidade de maneira mais sutil. Eventualmente, chegou-se a uma forma que continha traços relacionáveis com a identidade do sistema e que, em uma primeira análise superficial, poderia hierarquizar a informação de um modo ordenado. Essa solução foi selecionada para os testes seguintes. A Figura 15 mostra esse estudo.

Figura 15 Geração e Seleção de Alternativa

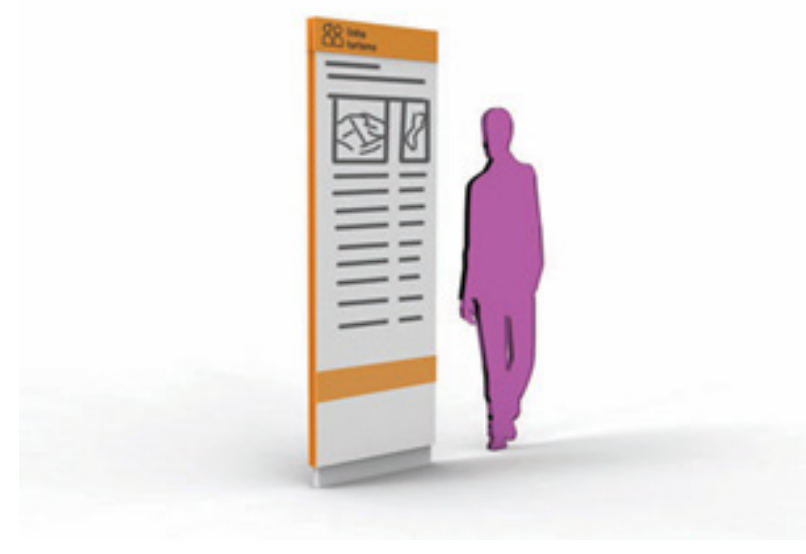

O primeiro esforço no Fechamento do Sistema foi a definição de dimensões, modulação e organização da informação. Isso ocorreu antes que a informação fosse de fato desenvolvida, tentando fornecer parâmetros a ela. A Figura 16 mostra essa organização.

Figura 16 Modulação do elemento de orientação

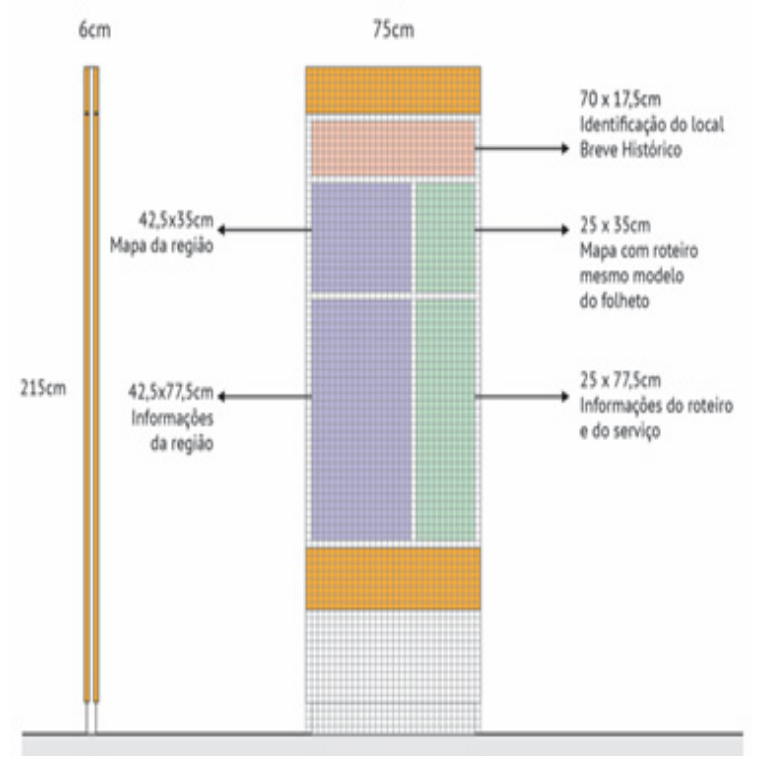


Com as dimensões gerais e o zoneamento criado, a informação começou a ser criada. Primeiro foi feito o mapa da região, mais realista que o mapa do roteiro, porém ainda com algum nível de simplificação. Ele utiliza outros materiais turísticos para marcar pontos de destaque na região e oferece uma relação de distância para os locais ao usuário, identificando sua localização e criando um raio de caminhada de 5 minutos ao seu redor. O preenchimento da peça com as informações foi cuidadoso, testando por meio de impressões em papel os tamanhos de fonte para os diferentes tipos de informação e alturas no elemento. A relação de campo visual e de distância de leitura da peça, para pessoas de pé e cadeirantes, foi determinante para essas escolhas (Figura 16).

Figura 17 Campo visual: pessoa de pé e cadeirante (1 metro de distância)
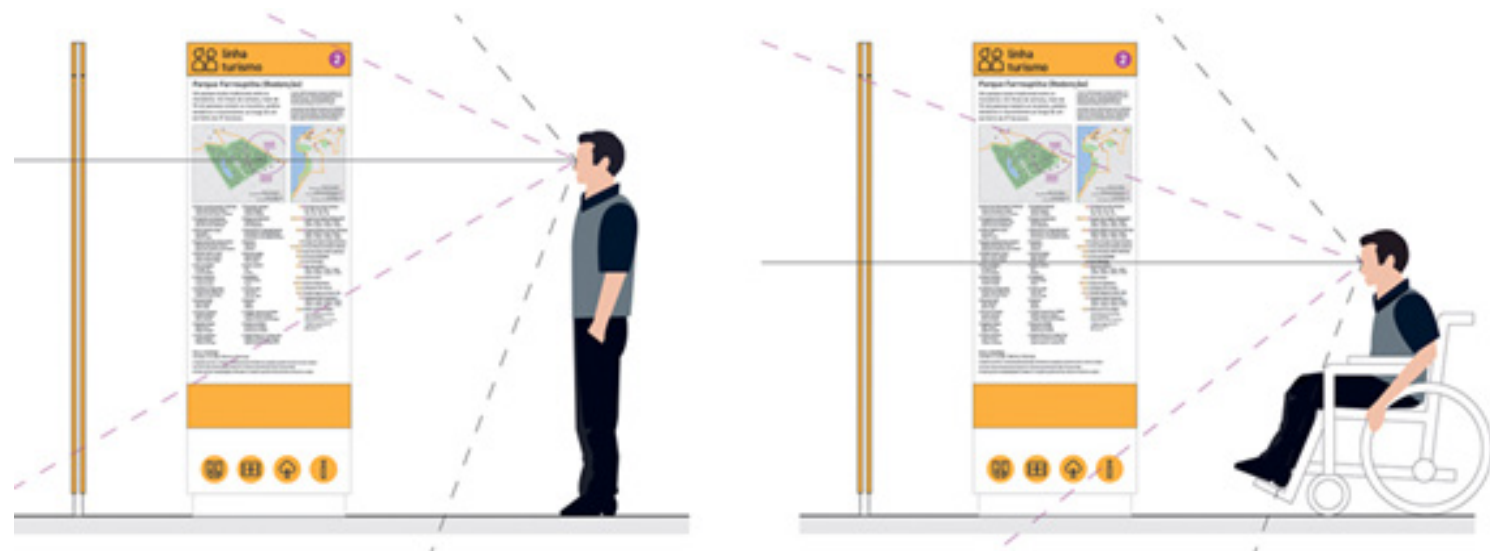

A informação utiliza os mesmos padrões estabelecidos no folheto. Na coluna da direita, o roteiro, junto com suas paradas, é apresentado em uma lista na qual os pictogramas indicam as características dos ambientes. O próprio elemento identifica esses pictogramas referentes à sua localização, também utilizando um número que indica a ordem desse local dentro do roteiro. A coluna da direita é dedicada à região, contendo o mapa e a lista dos locais indicadas no mesmo. A Figura 19, mais em frente, mostra o resultado do elemento de orientação após passar pela etapa de ajustes.

\section{Etapa 10 - Avaliação da Performance}

A Validação do Sistema foi separada em um grupo com identidade de marca e pontos de contato e outro grupo com o projeto de orientação. O primeiro grupo, assim como na Análise das Informações Coletadas, foi avaliado por pesquisa na internet (respondida por leigos e designers). De um modo geral, o projeto foi bem aceito, com poucas ressalvas quanto ao resultado. Em comparação com a identidade anterior, entendeu-se que a nova proposta conseguiu melhorar algumas percepções. Houve, no entanto, alguns relatos contrários a algumas escolhas como cores, desenho dos símbolos e adequação geral ao serviço. No entanto a falta de consenso com relação à maioria dos relatos não motivou ajustes no quesito identidade. 
O projeto de orientação foi validado por um grupo de especialistas (professores e profissionais) em sinalização e orientação. A análise foi feita com base em um modelo de escala real do elemento, no qual os especialistas puderam avaliar a leitura e adequação da informação. A leitura a 1 metro de distância, e inclusive distâncias maiores, mostrou-se efetiva. Algumas observações sobre identidade do elemento, reorganização de informações e grafismos e adaptações no mapa foram registradas para considerações posteriores.

Os Eventuais Ajustes ocorreram principalmente no elemento de orientação. $O$ folheto apenas incluiu uma legenda para os pictogramas, sugestão feita ao elemento de orientação que foi adaptada ao impresso (Figura 18).

Figura 18 Folheto

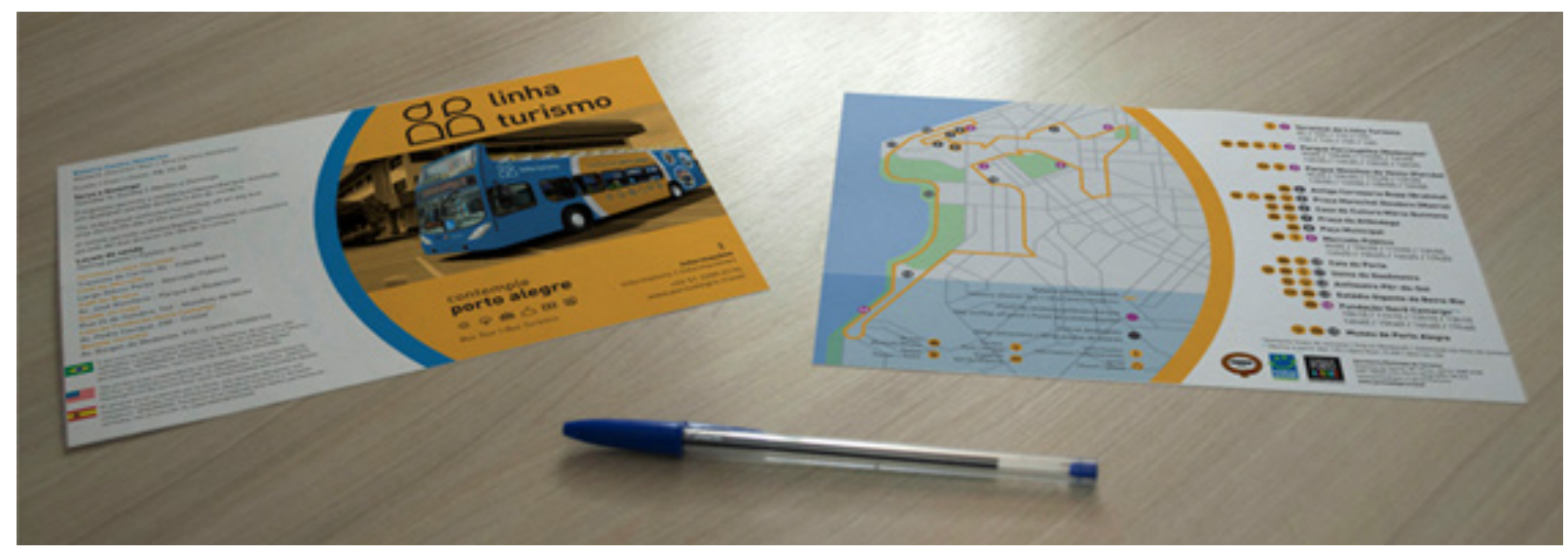

A principal alteração no elemento de orientação foi um aumento de cinco centímetros de largura. Esse redimensionamento foi necessário para um ajuste de tamanho dos pictogramas na lista. Fora isso, alguns ajustes no mapa e o acréscimo da cor azul para relacionar mais com a identidade foram aplicados. A Figura 19 mostra simulações do o elemento de orientação. 
Figura 19 Elemento de orientação

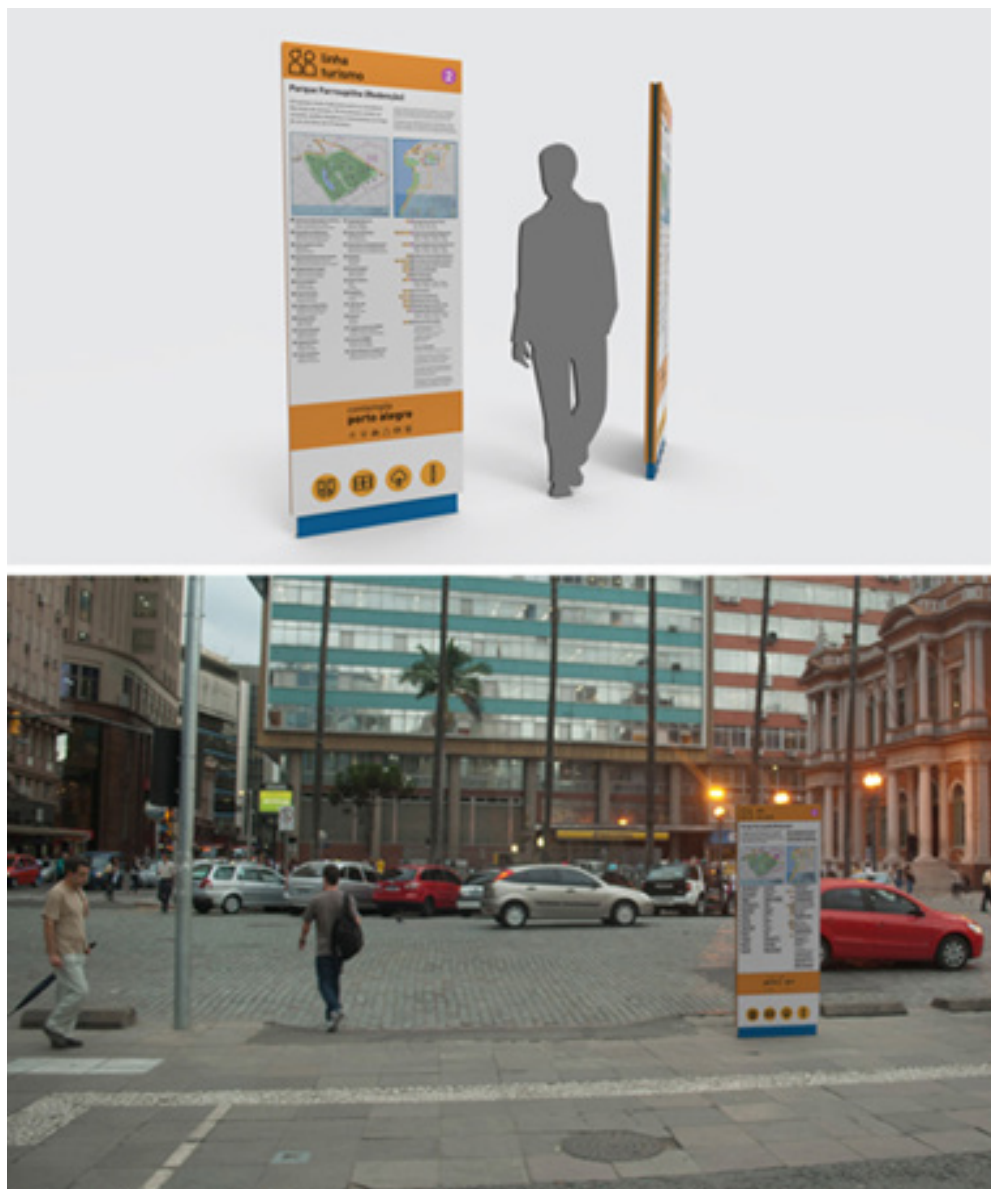

\section{Etapa 11 - Detalhamento}

A etapa concluída com o Manual do Sistema segue as recomendações de Wheeler (2008) e do NDGA (Cardoso et al, 2011). Nele, buscou-se prever diferentes situações que podem surgir para direcionar a aplicação da identidade da melhor maneira. A Figura 20 mostra algumas páginas do manual. 
Figura 20 Manual do Sistema
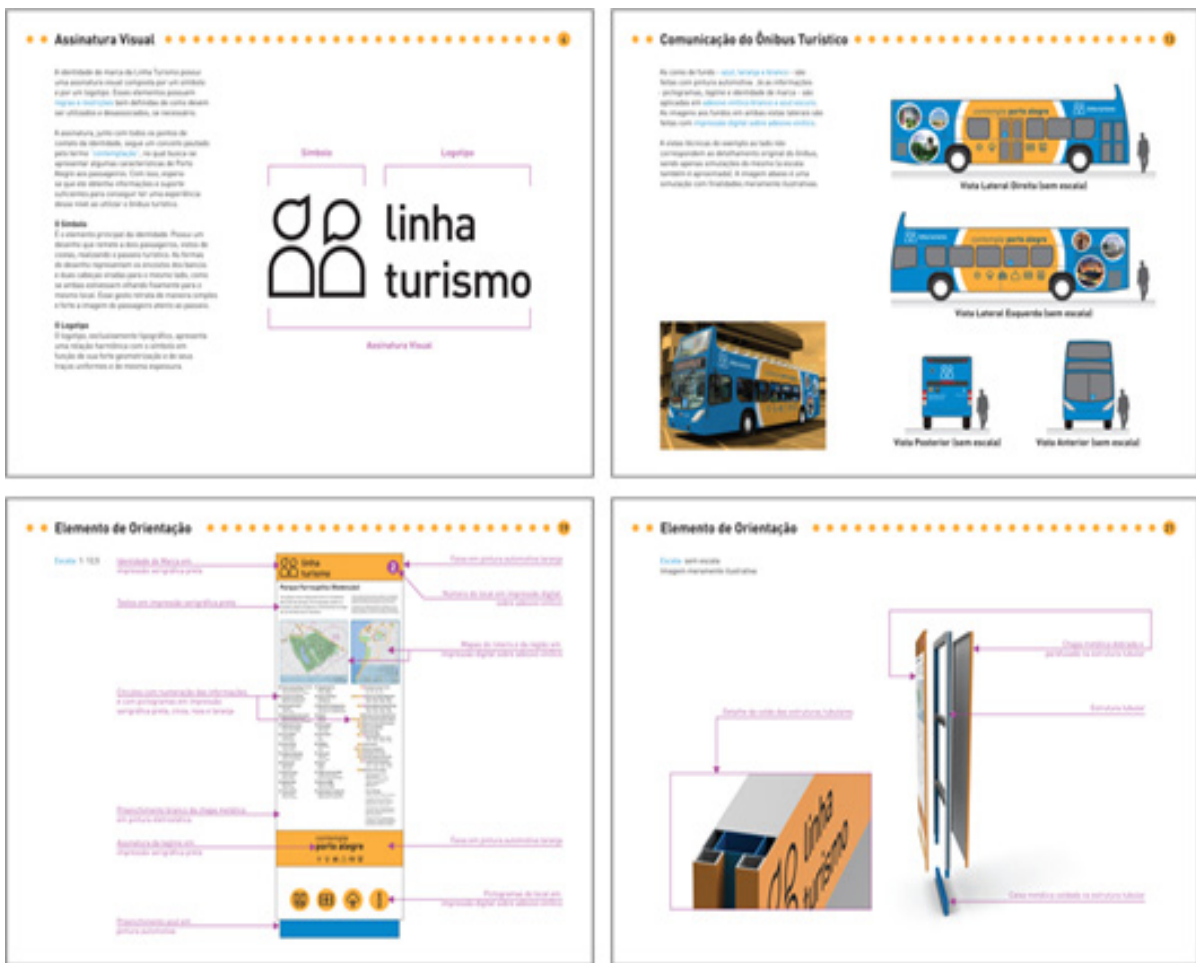

\section{Considerações Finais}

A necessidade de utilizar diversos métodos aconteceu muito naturalmente, uma vez que seria improvável a existência de uma metodologia que correlacionasse as três áreas do design aqui tratadas. Embora houvesse a possibilidade de se trabalhar apenas com um método mais abrangente em design, ficou logo claro que a situação requeria um tratamento específico.

A ideia de trabalhar com a Linha Turismo surgiu de maneira espontânea, sem uma real encomenda de projeto. O primeiro escopo foi, assumidamente, uma suposição pessoal das possibilidades dentro do contexto turístico, sem aprofundamento de viabilidade. Assim, o método de Frascara foi ideal por entender esse momento em que a visão do designer define a situação temporariamente.

Conforme as coletas de informações foram acontecendo, notou-se como as suposições iniciais não estavam longe da realidade. Cada novidade da Linha Turismo respaldava as pretensões do projeto e ajudava na definição do problema. Dessa maneira, diversos acontecimentos foram tornando a proposta mais relevante. 
Especificamente sobre os projetos, os métodos de Wheeler e do NDGA foram fundamentais para um processo criativo cuidadoso. "A Grande Ideia" foi trabalhada sem pressa de gerar um resultado. Da mesma maneira que, antes da forma do elemento de orientação, as extensas problematizações definiram a informação dos locais de maneira contundente.

O benefício do pensamento metodológico no resultado do projeto é sensível. Não é definitivo, mas teve importante papel em demonstrar que toda informação coletada pode ser relevante.

\section{Referências}

BOMFIM, G. A. 1995. Metodologia para desenvolvimento de projetos. João Pessoa: Editora Universitária/UFPB.

CALORI, C. 2007. Signage and Wayfinding Design: A Complete Guide to Creating Environmental Graphic Design Systems. Hoboken: John Wiley \& Sons.

CARDOSO, E. et al. 2011. Análise comparativa para contribuição metodológica em design de sinalização. In MENEZES, Marizilda dos S.; PASCHOARELI, Luiz Carlos; MOURA, Mônica (Orgs.). Metodologia em design: inter-relações. São Paulo: Estação das Letras e Cores, p. 31-47.

FRASCARA, J. 2004. Communication Design: principles, methods and practice. Canada: Allworth Press.

GIBSON, D. 2009. The Wayfinding Handbook: information design for public places. New York: Princeton Architetural Press.

SCHERER, G. B. 2012. Linha Turismo de Porto Alegre: Uma Contribuição do Design para Identidade, Informação e Orientação. Trabalho de Conclusão de Curso. Porto Alegre: Universidade Federal do Rio Grande do Sul. Orientação: Fabiano de Vargas Scherer.

SLESS, D. 2014. Why do information design? Disponível em <http:// communication.org.au/why-do-information-design/>. Acessado em 18/08/2014.

WHEELER, A. 2008. Design de Identidade da Marca. Porto Alegre: Bookman. 
Scherer, F. V., \& Scherer, G. B. | Estudo de Método Projetual para Sistema Integrado de Identidade Visual, Design da Informação e Orientação

\section{Sobre os autores}

Fabiano de Vargas Scherer,

Mestre, UFRGS<fvscherer@ufrgs.br >

Gabriel Bischoff Scherer,

Bacharel em Design, UFRGS<gabriel.scherer88@gmail.com>

Artigo recebido em 10 set. 2015,

aprovado em 21 set. 2015. 